\title{
Women's Opinion about Women's Rights regarding Family Planning in Hegarmanah Village, Jatinangor Subdistrict, West Java in 2013
}

\author{
Suzanne Saw, ${ }^{1}$ Yoni Syukriani, ${ }^{2}$ A. Hussein S. Kartamihardja ${ }^{3}$ \\ ${ }^{1}$ Faculty of Medicine Universitas Padjadjaran, ${ }^{2}$ Department of Forensic \& Legal Medicine Faculty \\ of Medicine Universitas Padjadjaran/Dr. Hasan Sadikin General Hospital Bandung, ${ }^{3}$ Department \\ of Nuclear Medicine Faculty of Medicine Universitas Padjadjaran/Dr. Hasan Sadikin General \\ Hospital Bandung
}

\begin{abstract}
Background: Universal Declaration of Human Rights stated that all mankind have equal right and dignity. Both woman and man have rights regarding family planning. It is often assumed that in developing country, women do not consider their rights in family planning decision making process. This study was carried out to determine the opinion of women regarding women's rights in family planning.

Methods: A descriptive study was carried out to 99 respondents during the period of August to October 2013, in Hegarmanah village, Jatinangor subdistrict. The inclusion criteria were women aged 15-49 years old, able to speak Bahasa Indonesia, and agreed to participate. Variables for this study were the opinions of the respondents regarding woman's rights in family planning which were represented in 12 questions. Collected data were presented as percentages shown in tables.

Results: Most of the respondents stated that they had the rights in family planning decision making, including choosing contraceptive methods, number of children, and spacing of each child. However, all of the respondents agreed that men should be involved in it. More than half of the respondents stated that they asked opinion from family member regarding family planning especially their mothers. Cultural norms did not influence the family planning decision making. However, religion influenced the family planning decision making.

Conclusions: Majority of the women in Hegarmanah village have the role to make decision on family planning by considering the opinions of their spouses, other family members, friends and their religions. [AMJ.2015;2(3):308-13]
\end{abstract}

Keywords: Cultural norms, family planning, men, religion, women's rights

\section{Introduction}

As stated in the Universal Declaration of Human Rights, all mankind have equal right and dignity. However, experts considered cultural and religious norms are still the barrier for women's rights in decision making. From the human right perspective and through the Millennium Development Goals, barriers to contraceptives can be recognized and reduced. ${ }^{1}$ According to traditional cultural norms, men are the most important factor in family life decision making. Both woman and man have rights on family planning and decision making that should involve spouse. The ability of spouse to choose and decide on the number, spacing, and timing of children has become the main focus of current international family planning programmes. ${ }^{2}$ There were many studies conducted regarding family planning but no study was conducted on woman's rights in family planning.

West Java is one of the provinces in Indonesia which has the largest population. It is the first province that implemented family planning programme and by the end of 2012, about $55.7 \%$ reproductive age population practiced family planning. ${ }^{2}$ Jatinangor as one of the subdistricts in West Java, is designated by the Faculty of Medicine Universitas Padjadjaran to be a subdistrict where medical students carried out researches on various health issues including family planning. Therefore, this study was conducted to determine the opinion of women regarding women's rights

Correspondence: Suzanne Saw, Faculty of Medicine, Universitas Padjadjaran, Jalan Raya Bandung-Sumedang Km.21, Jatinangor, Sumedang, Indonesia, Phone: +62 85793256929, Email : suzannesaw91@hotmail.com 
in family planning in Jatinangor.

\section{Methods}

A descriptive study was carried out to 99 respondents during the period of August to October 2013, in Hegarmanah village, one of the 12 villages in Jatinangor subdistrict. The inclusion criteria were women aged 15-49 years old, able to speak Bahasa Indonesia, and agreed to participate. The exclusion criteria were respondents who were not at home when the data were collected.

Variables for this study were the opinions of the respondents regarding women's rights in family planning consisting of 3 issues; first, the roles of men, women, and spouses, second, the roles of family and friends, third, the roles of cultural norms and religions. There were 12 questions that the respondents should respond in "yes" and "no" answers. The collected data were presented as percentages shown in tables. This study was approved by the Health Research Ethics Committee Faculty of Medicine Universitas Padjadjaran.

\section{Results}

Most of the respondents (47\%) were below 20 years old. All respondents were Muslim. There were 52 unmarried women and 47 married women in this study. For the characteristic of married women, all married women had history of pregnancy and had children. Only $9 \%$ had abortion and $91 \%$ of the respondents were using contraception. All of theunmarried women wanted to have children in the future and $87 \%$ planned to have $2-3$ children.

Moreover, $85 \%$ of the respondents planned to use contraception and the majority of them preferred the pill as a contraceptive method. Most of the respondents stated that they had rights in family planning decision making and played a role in deciding the number of children and spacing of each child. However, all respondents agreed that men should be involved in family planning decision making.

Only half of the respondents agreed that

Table 1 Roles of Men, Women and Spouses

\begin{tabular}{|c|c|c|}
\hline $\begin{array}{c}\text { Opinion of Women Regarding their Right in Family } \\
\text { Planning }\end{array}$ & Total (n) & Percentage $(\%)$ \\
\hline \multicolumn{3}{|l|}{ Men involvement in family planning decision making } \\
\hline Yes & 89 & 90 \\
\hline No & 10 & 10 \\
\hline \multicolumn{3}{|l|}{ Man involvement in contraception } \\
\hline Yes & 52 & 53 \\
\hline No & 47 & 47 \\
\hline \multicolumn{3}{|l|}{ Women have the right in family planning decision making } \\
\hline Yes & 91 & 92 \\
\hline No & 8 & 8 \\
\hline \multicolumn{3}{|l|}{$\begin{array}{l}\text { Role of woman in deciding the number of children, spacing } \\
\text { of each pregnancy }\end{array}$} \\
\hline Yes & 90 & 91 \\
\hline No & 9 & 9 \\
\hline $\begin{array}{l}\text { Spousal consent/inform spouses before access to } \\
\text { contraceptives }\end{array}$ & & \\
\hline Yes & 94 & 95 \\
\hline No & 5 & 5 \\
\hline \multicolumn{3}{|l|}{$\begin{array}{l}\text { women require to follow men's decision in family planning } \\
\text { even though woman do not agree with the decision }\end{array}$} \\
\hline Yes & 43 & 43 \\
\hline No & 57 & 57 \\
\hline
\end{tabular}


Table 2 Roles of Families and Friends

\begin{tabular}{lcc}
\hline \multicolumn{1}{c}{ Opinion of Women Regarding their Right in Family } & Total (n) & Percentage (\%) \\
\hline $\begin{array}{l}\text { Ask the opinion from family member regarding family } \\
\text { planning }\end{array}$ & \\
Yes & 60 & 61 \\
No & 39 & 39 \\
Ask the opinion from friends regarding family Planning & 51 & 48 \\
Yes & 48 & 48 \\
No & & 56 \\
Influences from family members regarding perception in & & 44 \\
family planning & 55 \\
Nes
\end{tabular}

men should be involved in using contraception and did not agree that women required to follow men's decisions in family planning.

More than half of the respondents stated that they asked opinion from family members regarding family planning and some of the respondents were influenced by family members especially their mothers.

Cultural norms did not influence the family planning decision making. However, religion influenced the family planning decision making.

\section{Discussion}

Women represented by $90 \%$ agreed that men should be involved in family planning. Out of
$90 \%$ respondents, $60 \%$ of them thought that men play a role in family planning. Besides, some women in Hegarmanah village stated that men should make decision in family planning as man is the head of family (Table 1). This result is similar to theInternational Conference and Demography Population (IICPD) held in Egypt ${ }^{3}$ that concluded in regard to women's rights in family planning, it should involve men in decision making.

Furthermore, respondents were asked about involvement of men in contraception and $53 \%$ of the respondents agreed that men should be involved in contraception. Out of $53 \%$ respondents, $34 \%$ of the women thought that men can use contraceptives method available for men. Some women thought that men had thesame responsibility in family

Table 3 Roles of Cultural Norms and Religion

\begin{tabular}{lcc}
\hline \multicolumn{1}{c}{ Opinion of Women Regarding their Right in Family } & Total (n) & Percentage (\%) \\
\hline $\begin{array}{l}\text { Planning } \\
\text { More children one has, it will be better }\end{array}$ & 42 & 42 \\
Yes & 57 & 58 \\
No & & \\
$\begin{array}{l}\text { If in the area less people were practicing family planning, } \\
\text { the respondents would still use contraception in controlling }\end{array}$ & & 90 \\
fertility & 89 & 10 \\
Yes & 10 & \\
No & & 66 \\
Religion influences decision making in family planning & 65 & 34 \\
Yes & 34 & \\
No & & \\
\hline
\end{tabular}


planning besides women. A study conducted in Tasikmalaya ${ }^{4}$ predicted that participation of men in contraception has increased from year to year, with rate $3.6 \%$ in $2010,4.0 \%$ in 2011 , $4.3 \%$ in $2012,4.6 \%$, in 2013 and $5.0 \%$ in 2014 . This study showed that participation of men in contraception has increased as one of the aims of theMillennium Development Goals 3 was to promote gender equality and empower women. Therefore, men have responsibility in using contraceptive methods available for men.

However, around half of the respondents represented by $47 \%$ thought that men should not use contraception. Whereas, around $41 \%$ stated that normally women used and men did not use contraception. Respondents stated that there was less option available for men and it was uncomfortable if men used contraception during sexual intercourse. Result in this study is similar to a study conducted in Tasikmalaya, ${ }^{4}$ which stated that majority of acceptors of family planning are women and most women do not support participation of husband in usage of contraception, as $76 \%$ do not allow husband to use condom and $86 \%$ are uncomfortable if their husbands use condom during sexual intercourse.

In addition, in a study conducted in the rural area of Jammu District ${ }^{5}, 74 \%$ of women and $67 \%$ of men think that only women should use contraception. In addition, a study conducted in Nigeria $^{6}$ only minority of respondents represented by $1.6 \%$ agree and $5.2 \%$ agree conditionally vasectomy as a method of contraception for men.

Regarding the women's rights in family planning decision making, majority of respondents (92\%) agreed that women have rights in family planning decision making. Around $65 \%$ of the women thought that reproductive health decision making should involve women. Women thought they have right to make decision in family planning because women are the ones who get pregnant, more contraceptive methods are available for women, and women bear the risks and burdens of pregnancy and childbearing.

According to the respondents, if women have rights in family planning, then women play a role in deciding the number of children and spacing of each pregnancy. This was proved by the result of this study, where by $91 \%$ of the women agreed that women played a role in deciding the number of children and spacing of each pregnancy. In addition, some respondents $(78 \%)$ stated that both husband and wife shared the same rights in family planning as well as in making a decision. In contrary to the study in Calabar Municipality ${ }^{3}$ more than half represented by $57 \%$ of women stated that their spouses should decide when to have thenext child. However, only $9 \%$ of women stated that the spouses have no right in deciding the number of children and spacing of each pregnancy.

Ninety four percent of women agreed that they should obtain spousal consent or inform spouses before access to contraception. Out of $94 \%$, around $60 \%$ agreed that men had rights to know and $33 \%$ stated that women must respect man as the head of family. A study in India ${ }^{7}$ shows that if a husband submits himself for an operation of sterilization without medical reason and consent or knowledge of his wife, and similarly if the wife undergoes vasectomy (read tubectomy) or abortion without medical reason and consent or knowledge of her husband, such an act of the spouses may lead to mental cruelty."

Therefore, women in Hegarmanah village respected their husbands in family planning decision making although they knew they had rights in family planning. This result is similar to a case study in Sumedang, West Java ${ }^{2}$ where most of the women ask their husband before making decision and it also stated that a man is the head of family and normally the decision makers. However, women and men discuss before decision making. In addition, a study in Nigeria ${ }^{5,8}$ have proven that communication affects decision in family planning.

Respondents represented by $61 \%$ obtained opinion from family members regarding family planning (Table 2). Most of the respondents asked for opinion from family members to obtain a better option. About $56 \%$ of the respondents told that family members influence their decision making. Besides, respondents stated that mother is the one who gives information and teaches them about family planning. This is similar to a case study conducted in Sumedang ${ }^{2}$ where information regarding family planning were normally obtained fromthe mother. Similarly, a study in India5 showed that $63 \%$ women from urban area and $35 \%$ of women from rural area obtain information regarding family planning from family members.

Moreover, respondents in this study asked opinion from friends regarding family planning besides from family members. Around $52 \%$ of the respondents asked opinion from friends to get a better option. However, $48 \%$ of the respondents stated that friends should not be involved in family planning. 
From this point of view, not all women are influenced by friends regarding their rights in family planning decision making. In a study conducted in Calabar Municipality ${ }^{3}$ and Obudu municipality ${ }^{3}, 1.3 \%$ of the respondents are influenced by their friends in family planning decision making. The result is similar to this study as some of the respondents were influenced by friends in family planning decision making.

Respondents represented by $56 \%$ were influenced by their family members (Table 2). While, the majority stated that mother taught them about family planning and this was represented by $30 \%$. Mother is the important factor in therespondents' opinion regarding their rights in family planning in Hegarmanah village. This result is in accordance with findings of a case study in Sumedang, West Java, ${ }^{2}$ where women use contraception as told by their mothers until they give birth to first child as they are ready and thereafter, their mother are not influencing their perception as it is up to them to decide. However, in Calabar ${ }^{3}$ and Obudu Municipality ${ }^{3}$ represented by $65 \%$ and $58 \%$ respectively, women stated that influence by views of their spouses in family decisions are higher in comparison to family members, friends and relatives.

More than half of therespondents (58\%) did not agree with the statement that "the more children will be better" (Table 3 ). While, economically, cannot sustain the children needs is one of the main reasons that caused respondents did not agree with the statement. Besides, according to Islamic family planning, it is stated in the Qur'an that parents have responsibility towards their children ${ }^{9}$

However, respondents represented by $42 \%$ agreed that "the more children will be better." Around $18 \%$ stated that a child is a gift from God. This perception is similar to a study conducted in Nigeria10 that people believe having many children is an advantage and a blessing from God.

Respondents represented by $90 \%$ would still practice family planning if in the area less people used contraception in controlling fertility (Table 3). This representation showed that in Hegarmanah village, cultural norms did not influence women's rights in decision making regarding family planning. This result is similar to a study conducted in Nigeria ${ }^{9}$ where there are no influences on cultural norms towards choice of family planning. Most of the respondents represented by $59 \%$ stated that they would still use contraception because it is their right.
In this study, religion influenced decision making in family planning represented by $66 \%$. Most of the respondents told that they must respect their religion perspectives, moreover religion is important for them. This result is similar to a study conducted in Zone 5 barracks of Nigeria Police ${ }^{10}$ where there is a relationship between religious belief and decision making in family planning in married women. In conclusion, majority of the women in Hegarmanah village think that men and women play a role in family planning decision making but women stated that they have right to make decision for themselves.

This study has limitations, therefore, a further study should be carried out involving men, family members especially mothers, friends and also religious leaders.. This study was carried out in one village that did not necessarily represent the entire Jatinangor subdistrict and only explored the point of view of the women. .

It can be concluded that women have a role in making decision in family planning by considering the opinions of their spouses, other family members, friends and their religions.

\section{References}

1. Cottingham J, Germain A, Hunt P: Use of human rights to meet the unmet need for family planning. Lancet. 2012;380(9837):172-80.

2. Herarti, R. Family planning decisionmaking: case studies in West Java, Indonesia. The 12th Biennial Conference of the Australian Population Association. 2004 September 15-17; Canberra: APA,2004; Canberra,Australia.

3. Undelikwo VA, Osonwa OK, Ushie MA, Osonwa RH. Family planning behaviours and decision making among couples in Cross River State, Nigeria. International Journal of Learning and Development. 2013;3(1):100-20.

4. Istiqomah $\mathrm{A}$, Novianti $\mathrm{S}$, Nurlina. Male participation in family planning in Tasikmalaya. [cited 2013 May 25 ] Available from: http://journal.unsil.ac.id/ download.php?id=655.

5. Dhingra R, Manhas S, Kohli N, Mushtaq A. Attitude of couples towards family planning. J Hum Ecol. 2010;30(1):63-70.

6. Akpamu U, Nwoke EO, Osifo UC, Igbinovia ENS, Adisa AW. Knowledge and acceptance of vasectomy as a method of contraception amongst literate married men in Ekpoma, 
Nigeria. Afr J Biomed Res. 2010;13(2):1536.

7. Pai NB, Rao S, Kosgi S, Undaru SB, Hedge V. Women reproductive rights in India: prospective future. Online J Health Allied Scs. 2011;10(1):1-5

8. Oladeji D. Communication and decision making factors influencing couples interest in family planning and reproductive health behaviours in Nigeria. Stud Tribes Tribals. 2008;6(2):99-103.
9. Olaitan, Lanre O. Factors influencing the choice of family planning among couples in South West Nigeria. Int J Med Med Sci. 2011;3(7):227-32.

10. Igbudu U, Okoedion SO, Peremene EB, Eghafona KA. Religious beliefs and family planning practises married women in zone 5 , police barracks in Nigeria. Ozean Journal of Social Sciences. 2011:4(2):55-6. 